\title{
Sosiomateriaalinen näkökulma vuorovaikutukseen muuttuvissa työtiloissa
}

\section{Ari Kuismin}

\begin{abstract}
Viittausohje:
Kuismin, A. (2021). Sosiomateriaalinen näkökulma vuorovaikutukseen muuttuvissa työtiloissa. Prologi Viestinnän ja vuorovaikutuksen tieteellinen aikakauslehti, 17(1), 30-35. https://doi.org/10.33352/prlg.111723

To cite this article:

Kuismin, A. (2021). Sosiomateriaalinen näkökulma vuorovaikutukseen muuttuvissa työtiloissa [Interacting in new spaces of work: A sociomaterial perspective]. Prologi - Journal of Communication and Social Interaction, 17(1), 30-35. https://doi.org/10.33352/prlg.111723
\end{abstract}

Prologi

- Viestinnän ja vuorovaikutuksen tieteellinen aikakauslehti journal.fi/prologi/

ruotsiksi: Prologi - Tidskrift för Kommunikation och Social Interaktion englanniksi: Prologi - Journal of Communication and Social Interaction Julkaisija: Prologos ry.

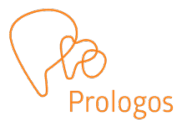

Avoin julkaisu / Open Access ISSN 2342-3684 / verkko ISSN 1795-7613 / painettu versio 


\section{Keynote-puheenvuoro}

Prologi, 17(1)

30-35

https://doi.org/10.33352/prlg.111723

\section{Sosiomateriaalinen näkökulma}

\section{vuorovaikutukseen muuttuvissa työtiloissa}

Ari Kuismin

Apulaisprofessori

Viestintä, Jyväskylän yliopisto

ari.j.kuismin@jyu.fi

vastaanotettu 15.10. / hyväksytty 19.10. / julkaistu 15.11.2021

ASIASANAT: työtila, vuorovaikutus, organisaatio, sosiomateriaalisuus, yhteismuotoutuminen

Keynote-puheenvuoro, Vuorovaikutuksen teemapäivä 8.10.2021

\section{Johdanto}

Työelämään ja organisaatioihin ovat viime vuosina vaikuttaneet monet eri muutokset. Yksi voimakkaimmista muutoksista koskee sitä, missä töitä tehdään eli työnteon tiloja. Jo ennen korona-aikaa niin tutkimuksissa kuin työpaikoilla pohdittiin sitä, miten tila vaikuttaa työhön ja sen organisointiin niin kotikonttoreissa, toimistoissa kuin yhteistyöskentelytiloissa (Kinnunen, Lempiäinen ja Peteri, 2017; Ropo ym., 2015). Tutkimuksissa on tarkasteltu muun muassa tilan roolia ihmisten välisen vuorovaikutuksen edistämisessä, työntekijöiden oppimisen tukemisessa sekä inklusiivisuuden ja monimuotoisuuden vahvistamisessa. Viime aikoina huomiota on kiinnitetty erityisesti siihen, miten työnteon tilat vaikuttavat ihmisten toimijuuteen eli kykyyn ja mahdollisuuksiin toimia tai vaikuttaa erilaisiin työhön liittyviin tilanteisiin (Stephenson ym., 2020). Tutkijat ovat esittäneet, että tila ei ole vain passiivinen työnteon tausta. Sen sijaan, tilalla itsellään voidaan ymmärtää olevan toimijuutta sekä aktiivinen vaikutus ihmistoimijuuden muotoutumiseen.

Tässä puheenvuorossa keskityn siihen, miten tilan ja ihmistoimijuuden välistä suhdetta voidaan tutkia niin kutsutusta sosiomateriaalisesta näkökulmasta erityisesti organisaatioiden ja muuttuvan työelämän kontekstissa. Esitän, että parempi ymmärrys tilan vaikutuksesta ihmistoimijuuden muotoutumiseen on keskeinen osa tasa-arvoisemman, oikeudenmukaisem- 
man ja sosiaalisesti kestävämmän työelämän rakentamista tilanteessa, jossa lähes kaikki yhteiskunnan tilat voidaan nähdä mahdollisina tietotyön tiloina. Tarkastelen aluksi sitä, miten tilan ja työntekijöiden välistä suhdetta on perinteisesti hahmotettu organisaatiotutkimuksen kirjallisuudessa. Tämän jälkeen esittelen sosiomateriaalisen näkökulman keskeiset oletukset ja hahmottelen sitä, miten tämä näkökulma lähestyy tilan ja ihmistoimijuuden välistä suhdetta. Esimerkkien kautta havainnollistan, kuinka sosiomateriaalisuuden käsite siirtää huomion ihmisen ja tilan vuoroin vaikuttamisesta (inter-action) niiden yhteismuotoutumiseen (intra-action) eli rakentumiseen yhdessä (Barad, 2007). Puheenvuoron lopuksi esitän muutamia päätelmiä siitä, millaisia eväitä sosiomateriaalinen näkökulma tarjoaa työtilojen suunnittelulle ja muokkaamiselle.

\section{Tila organisaatiotutkimuksen kohteena}

Organisaatiotutkimuksen kirjallisuudessa työnteon tiloja on perinteisesti lähestytty kahdesta eri näkökulmasta. Ensimmäinen näkökulma keskittyy ihmistoiminnan tarkastelemiseen erityisesti sen suhteen, millaisia kokemuksia työtilat synnyttävät ja millaisia tulkintoja me ihmiset tiloista teemme (Ropo ym., 2015). Tästä näkökulmasta on tutkittu esimerkiksi sitä, miten organisaation käyttämiin rakennuksiin liitetyt sosiaaliset merkitykset vaikuttavat ihmisten käsityksiin organisaation legitimiteetistä eli toiminnan yleisestä hyväksyttävyydestä (De Vaujany ja Vaast, 2014). Tutkijat ovat niin ikään perehtyneet siihen, miten tiloista tehdyt tulkinnat vaikuttavat niissä työskentelevien ihmisten toimintaan, pukeutumiseen ja puhetapoihin (Tyler ja Cohen, 2010). Tästä näkökulmasta toimijuus hahmottuu eritoten inhimillisenä omi- naisuutena, joka esiintyy suhteessa tilojen viestimiin sosiaalisiin ja symbolisiin merkityksiin.

Toinen näkökulma siirtää painotuksen ihmistoiminnasta fyysisiin tiloihin ja erityisesti niiden ominaisuuksiin, vaikutuksiin ja käyttömahdollisuuksiin. Tutkimuskirjallisuudessa on osoitettu muun muassa se, miten tietynlaiset tilajärjestelyt kuten avotilat tai yhteistyöskentelytilat voivat vaikuttaa sekä myönteisesti että kielteisesti työntekijöiden väliseen vuorovaikutukseen, ja miten tietty sisälämpötila tai valaistus on yhteydessä ihmisten työssäjaksamiseen (Elsbach ja Pratt, 2007). Huomiota on kiinnitetty niin ikään siihen, miten työntekijät voivat käyttää suunniteltuja työtiloja niiden käyttötarkoitusten vastaisesti ja näin vastustaa tilojen kautta harjoitettua työntekijöiden kehojen kontrollia (Taylor ja Spicer, 2007). Myös tämä näkökulma hahmottaa toimijuuden erityisesti inhimillisenä ominaisuutena, jota ihmiset harjoittavat suhteessa materiaaliseen ympäristöönsä esimerkiksi muokkaamalla sitä tarpeidensa mukaisesti.

Vaikka nämä kaksi näkökulmaa eroavat toisistaan merkittävällä tavalla, ne molemmat rakentuvat oletukselle siitä, että inhimilliset tai sosiaaliset ilmiöt ovat perustalla tavalla erillisiä suhteessa materiaalisiin ilmiöihin. Molemmat näkökulmat kyllä huomioivat ihmisen ja tilan välisen väistämättömän vuorovaikutuksen, mutta hahmottavat sen olevan toisistaan erillisten entiteettien välinen suhde. Useat organisaatiotutkijat ovat viime vuosina esittäneet, että tällaiset erotteluihin perustuvat lähestymistavat ovat monella tapaa ongelmallisia (Cooren, 2020; Orlikowski, 2007). Jos esimerkiksi mietitään mitä tahansa organisaation tilaa, pitää se tavallisesti sisällään sekä sosiaalisia että materiaalisia elementtejä samanaikaisesti ja vaikeasti erotettavalla tavalla. Tilassa on näin ollen kyse 
niin sosiaalisista merkityksistä kuin materiaalisista piirteistä yhtä aikaa.

Seuraavassa kerron tarkemmin siitä, miten sosiomateriaalinen näkökulma auttaa meitä huomioimaan tämän tilan moninaisen ja dynaamisen luonteen. Keskityn erityisesti siihen, miten tämä näkökulma kutsuu meitä tutkimaan tilan ja ihmistoimijuuden välistä suhdetta yhteismuotoutumisena.

\section{Sosiomateriaalinen näkökulma työtiloihin}

Sosiomateriaalinen näkökulma voidaan ymmärtää teoreettiseksi viitekehykseksi, joka auttaa meitä ymmärtämään ihmisten ja materiaalisen ympäristön välistä monimutkaista suhdetta. Näkökulma haastaa sen perinteisen ajatuksen, että ihmiset ovat vuorovaikutuksessa materiaalisen ympäristönsä kanssa siitä erillisinä toimijoina. Huomio keskittyy sen sijaan siihen, että ihmisten ja materiaalisen ympäristön välisessä suhteessa on kyse niin kutsutusta yhteysmuotoutumisesta (Barad, 2007; Orlikowski, 2007). Tämä tarkoittaa, että tilojen, ihmiskehojen, teknologioiden ja muun materiaalisen ajatellaan rakentuvan perustavalla tavalla yhdessä kielen, kommunikaation ja muun sosiaalisen kanssa. Sosiomateriaalinen näkökulma näin ollen kiistää sellaiset erottelut kuin objektisubjekti ja luonto-kulttuuri. Se paremminkin kysyy, miten tällaiset erottelut ovat tulleet mahdollisiksi ja mikä niitä ylläpitää. Kantava ajatus tällöin on se, että sosiaalisia ilmiöitä on mahdoton ymmärtää ottamatta huomioon materiaalisuutta, ja vastaavasti materiaalisia ilmiöitä on mahdoton ymmärtää ottamatta huomioon sosiaalisuutta. Tutkijat viittaavat niin kutsuttuun relationaaliseen ontologiaan, joka ei anna etusijaa inhimilliselle tai materiaaliselle vaan keskittyy paremminkin näiden toimintaan yhdessä - tiettyjen ilmiöiden sisällä.

Sosiomateriaalinen näkökulma rakentuu lisäksi oletukselle siitä, että toimijuus ei ole yksinomaan inhimillinen piirre vaan pikemminkin useiden toimijoiden välillä jaettu ja yhdessä tuottama ominaisuus. Tämä tarkoittaa, että toimijuus on aina perustavalla tavalla riippuvaista sosiomateriaalisista suhteista, jotka antavat sille tilannekohtaisen muodon (Cooren, 2020). Tämä ei tarkoita, että ihmiset toimisivat täysin ilman autonomiaa, tarkoituksellisuutta tai tietoisuutta. Sosiomateriaalinen näkökulma pikemminkin esittää, että nämä piirteet pitävät aina sisällään myös materiaalisia elementtejä. Organisaatio- ja tietojärjestelmäteoreetikko Wanda Orlikowski (2007) käyttää Googlen hakukonetta esimerkkinä tällaisesta jaetusta toimijuudesta. Sen sijaan, että hakutulos olisi riippuvainen yksinomaan autonomisesta ihmistoimijasta tai teknologiasta, sen tuottamiseen osallistuu monimutkainen toimijoiden verkosto yhdessä. Tämä verkosto pitää sisällään niin käyttäjän, ylläpitäjien, laitteiston kuin algoritmien monimutkaiset ja samanaikaiset vaikutukset. Keskittyminen toimijuuteen yksinomaan ihmisyksilöiden ominaisuutena ei siten ole riittävä lähtöpiste sosiomateriaaliselle analyysille.

Sen lisäksi, että sosiomateriaalinen näkökulma painottaa entiteettien yhteismuotoutumista ja vie huomion toimijuuden jakautuneisuuteen, se nojaa oletukselle kaiken olevaisen prosessuaalisesta ja kehkeytyvästä luonteesta. Tämä tarkoittaa sitä, että asiat ja ilmiöt hahmotetaan aina ajassa kehittyviksi ja muuntuviksi. Niiden kulloinenkin muoto ja ominaispiirteet riippuvat niistä tilannekohtaisista sosiomateriaalisista suhteista, jotka antavat asioille ja ilmiöille niiden olevaisuuden. Toisin sanoen, asiat ja ilmiöt ovat jatkuvassa tulemisen (becoming) tilassa; ne 
muotoutuvat ja ne tehdään olevaisiksi sen sijaan, että niillä olisi jokin ennalta määrätty tai pysyvä ominaismuoto.

Miten sitten hahmottaa ihmistoimijuuden ja tilan välistä suhdetta sosiomateriaalisesta näkökulmasta? Tämä näkökulma ensinnäkin haastaa perinteisen näkemyksen tilasta vakaana fyysisenä säiliönä, joka on täytetty organisaation jäsenillä, toiminnoilla ja artefakteilla. Sen sijaan, tila hahmottuu samaan aikaan sekä sosiaalisesti että materiaalisesti tuotettuna (Stephenson ym., 2020). Tämä tarkoittaa, että tila ei vain ole "tuolla jossain" valmiina käytettäväksi ja tutkittavaksi. Tila paremminkin jatkuvasti tehdään olemassa olevaksi erilaisten yhteismuotoutumisen prosessien kautta. Etätyö tarjoaa tästä kuvaavan esimerkin. Kuten monet meistä tietävät, etätyöntekijöillä ei useinkaan ole selkeästi erillistä kotitilaa ja työtilaa vaan nämä tilat jatkuvasti järjestellään ja uudelleen järjestellään kulloisenkin tilanteen mukaisesti.

Sosiomateriaalinen näkökulma niin ikään kutsuu meitä tutkimaan sitä toimijoiden monimutkaista verkostoa, joka osallistuu tilan jatkuvaan ja tilannekohtaiseen tuottamiseen. Sen sijaan, että tila olisi vain seiniä, ovia ja ikkunoita, sosiomateriaalinen näkökulma herkistää meitä analysoimaan monia ja kenties jopa yllättäviä elementtejä, jotka yhdessä aikaansaavat tilan kulloisellakin hetkellä. Arkkitehtuurin ohella tilan tuottamiseen osallistuvat näin ollen myös tilaa koskevat diskurssit, tunteet, muistot, artefaktit, äänet, valot, hajut sekä lukuisat muut elementit samanaikaisesti. Sosiomateriaalinen näkökulma ei anna ensisijaisuutta millekään näistä elementeistä erityisesti. Sen sijaan, se tarkastelee kuinka ne yhdessä toimiessaan - toinen toisiaan muokaten - tekevät tilan.

Kenties olennaisinta tämän puheenvuoron kannalta on kuitenkin se, että sosiomateriaa- linen näkökulma ohjaa meitä hahmottamaan tilan ja ihmistoimijuuden välistä suhdetta yhteismuotoutumisena. Tämä tarkoittaa sitä, että ihmistoimijuus rakentuu aina suhteessa materiaaliseen tilaan - yhdessä tilan jatkuvan kehkeytymisen kanssa. Tästä näkökulmasta ihmiset eivät vain käytä tai muokkaa tilaa, vaan tila on paremminkin aktiivinen osa ihmisten tilanteisesti määrittyvää toimintakykyä ja -mahdollisuuksia. Se miten tila tulee osaksi ihmistoimijuutta, on kuitenkin aina tilanneyhteydestä riippuvaista. Yleistettävien mallien muodostamisen sijaan onkin olennaisempaa pohtia niitä eri tapoja, joilla tila prosessuaalisena ja eri aistein koettavana sosiomateriaalisena kokonaisuutena tulee osaksi ihmistoimijuuden muotoutumista. Olennaiseksi kysymykseksi kohoaa se, mitä tila tekee suhteessa ihmistoimijuuteen ja millainen ihmistoimijuus on mahdollista suhteessa tilaan.

\section{Muutokset työtiloissa muokkaavat toimijuuden mahdollisuuksia}

Mikäli tilan ja ihmistoimijuuden välisessä suhteessa on kyse yhteismuotoutumisesta, kuinka meidän tulisi sitten ajatella työtilojen muutoksista kuten uusista tilajärjestelyistä, hybridityöstä ja monipaikkatyöstä? Seuraavassa esitän, että nämä muutokset on mahdollista ymmärtää interventioina tilan ja ihmistoimijuuden väliseen yhteismuotoutumiseen. Näin ollen ne osaltaan vaikuttavat siihen, millainen ihmistoimijuus moderneissa työnteon tiloissa - ja laajemmin ottaen modernissa työelämässä - voi tulla mahdolliseksi ja millainen taas ei.

Otetaan seuraavaksi esimerkki, joka kuvaa työtilamuutosten luonnetta interventioina. Tässä esimerkissä tutkijat Alison Hirst ja Christina Schwabeland (2018) tutkivat asiantuntijaorganisaation muuttoa perinteisestä toimistoraken- 
nuksesta avokonttoriin. Muuton tarkoituksena oli lisätä vuorovaikutusta työntekijöiden välillä sekä leikata organisaation yleistä byrokraattisuutta. Uusien työtilojen pääasiallisena rakennusmateriaalina käytettiin lasia, ja tiloihin suunniteltiin monia oleskelualueita sekä spontaaneja kohtaamisia tuottavia kulkureittejä. Tutkimuksessa havaittiin, että muutokset työtiloissa kyllä lisäsit avoimuutta työntekijöiden välillä, mutta myös jättivät heidät ilman suojaa ja mahdollisuutta vetäytyä omiin oloihinsa. Tämä tilojen tuottama pakottava avoimuus taas teki mahdolliseksi häiritsevän ja seksistisen käyttäytymisen lisääntymisen tutkitussa organisaatiossa. Tutkijat kuvaavat esimerkiksi sitä, miten ryhmä miehiä pisteytti ja vertaili avointa työpaikkaa hakeneiden naiskandidaattien viehättävyyttä lasiseinän takaa. Organisaatiossa työskennelleet naiset taas olivat aikaisempaa tietoisempia siitä mahdollisuudesta, että he olivat jatkuvan tarkkailun alaisena uusissa työtiloissa. He päätyivät kiinnittämään entistä enemmän huomiota omaan statukseensa. $\mathrm{He}$ esimerkiksi alkoivat pukeutua entistä kalliimpiin vaatteisiin.

Tämä esimerkki nostaa tarkasteluun sen, miten työtilojen muutokset toimivat interventioina tilan ja ihmistoimijuuden väliseen yhteismuotoutumiseen työpaikoilla. Moderneihin, lasiseininistä rakennettuihin työtiloihin siirtyminen vahvisti tässä tapauksessa kulttuurissa esiintyvää seksististä käyttäytymistä ja toisaalta asetti rajoituksia seksismin kohteiden toimintamahdollisuuksien vahvistumiselle. Toisin sanoen, tilamuutos, jolla pyrittiin muuttamaan byrokraattisia valtasuhteita, päätyi voimistamaan sukupuoleen kytkeytyviä valtasuhteita. Olennaista tästä esimerkistä on siten huomata, että yhteismuotoutumisen interventioina tilamuutokset eivät välttämättä kohtele kaikkia yksilöitä ja ryhmiä samalla tavalla. Sen sijaan, ne voivat vaikuttaa tavoilla, jotka jopa vahvistavat epätasa-arvoisia erontekoja.

\section{Lopuksi}

Työelämän ja organisaatioiden muutokset materialisoituvat työnteon tiloissa. Olen tässä puheenvuorossa esittänyt, että näitä työtiloihin liittyviä muutoksia on syytä tarkastella suhteessa ihmistoimijuuden muotoutumiseen, ja että sosiomateriaalinen näkökulma tarjoaa tähän tarkoitukseen hyödyllisen lähestymistavan. Tämä näkökulma kutsuu meitä tutkimaan sitä, miten ihmisten toimintamahdollisuudet ja -kyvyt rakentuvat aina yhdessä tilan kanssa. Ihmisten suhde tilaan voidaan näin ollen ymmärtää yhteismuotoutumisena, jossa tila itsessään harjoittaa toimijuutta ja jossa ihmistoimijuus määrittyy.

Työelämän muutokset kuten siirtyminen avotoimistoon, kotikonttoriin tai monipaikkatyöhön voidaan näin ollen ymmärtää interventioita, jotka väistämättä muokkaavat ihmistoimijuuden rakentumisen mahdollisuuksia. Olen esimerkin valossa tuonut esiin sen, miten tällaiset interventiot voivat kohdella eri ihmisryhmiä ja yksilöitä eri tavoilla esimerkiksi sukupuolen suhteen. Sama tilamuutos voi näin ollen vahvistaa yhden ryhmän toimijuutta, mutta heikentää toisen. On myös tärkeää muistaa, että kaikilla yksilöillä ja ryhmillä ei välttämättä ole yhtäläisiä mahdollisuuksia tai pääsyä sellaisiin työnteon tiloihin, jotka vaikuttaisivat heidän toimijuuteensa myönteisellä tavalla. Voidaan kysyä, kenen toimintamahdollisuuksia esimerkiksi hybridityö edistää ja kenen taas ei? Entä kenen toimijuutta rajoitetaan tarkoituksellisesti tai tarkoittamatta pitämällä heidät tietyissä työnteon tiloissa? 
Tästä päästään siihen, millaisia eväitä sosiomateriaalinen näkökulma tarjoaa työtilojen suunnittelulle ja muutoksille. On ensinnäkin olennaista havaita, että tilassa ei ole vain kyse symbolisista merkityksistä tai tietyistä ominaisuuksista. Sen sijaan, tila tulee ymmärtää aktiivisena toimijana ihmistoimijoiden rinnalla. Tiloja muokatessa on siten syytä tarkastella, mitä tila tekee kulloisessakin tilanteessa. Kenet se yhdistää, kenet se erottaa ja millaisen toiminnan se vahvistaa tai tekee mahdottomaksi? Koska samat tilat voivat vaikuttaa ihmistoimijuuteen kovin eri tavoilla, on keskeistä ottaa tilojen käyttäjät mukaan niiden suunnitteluun ja jatkuvaan ylläpitämiseen. On tärkeää pohtia, kenen ehdoilla tilajärjestelyjä toteutetaan ja tilan arkisia pelisääntöjä neuvotellaan.

On myös olennaista muistaa, että tila ei ole ominaispiirteiltään muuttumaton vaan paremminkin jatkuvasti kehittyvä ja kehkeytyvä. Muutokset tilassa eivät välttämättä ole aina järisyttäviä siirtymiä, mutta ajan kuluessa tila väistämättä tulee toisenlaiseksi. Seiniä kaadetaan, merkityksiä neuvotellaan, rituaaleja ylläpidetään ja tilallisia kokemuksia kerrostetaan. Nämä ajassa kehittyvät tilamuutokset tarkoittavat myös muutoksia ihmistoimijuuden mahdollisuuksille. Työnteon tiloja suunniteltaessa onkin olennaista tarkastella kriittisesti sitä, miten tilan ja ihmistoimijuuden yhteismuotoutuminen voisi järjestyä nykyistä suotuisammin. Meidän tulee kysyä, mitkä tilalliset interventiot ovat tarpeen, jotta entistä useamman toimijuus voisi vahvistua työpaikoilla.

\section{Kirjallisuus}

Barad, K. (2007). Meeting the universe halfway. In Meeting the universe halfway. Durham: Duke University Press.

Cooren, F. (2020). Beyond entanglement: (Socio-) materiality and organization studies. Organization Theory, 1(3), DOI: 10.1177/2631787720954444.

De Vaujany, F. X., \& Vaast, E. (2014). If these walls could talk: The mutual construction of organizational space and legitimacy. Organization Science, 25(3), 713-731.

Elsbach, K. D., \& Pratt, M. G. (2007). The physical environment in organizations. Academy of Management Annals, 1(1), 181-224.

Hirst, A., \& Schwabenland, C. (2018). Doing gender in the 'new office. Gender, Work \& Organization, 25(2), 159-176.

Kinnunen, M., Lempiäinen, K., \& Peteri, V. (2017). Konttorista monitilatoimistoksi: työn tilojen etnografinen analyysi. Sosiologia, 54(2), 110-127.

Orlikowski, W. J. (2007). Sociomaterial practices: Exploring technology at work. Organization studies, 28(9), 1435-1448.

Ropo, A., De Paoli, D., Salovaara, P., \& Sauer, E. (2015). Leadership in spaces and places. Cheltenham: Edward Elgar Publishing.

Stephenson, K. A., Kuismin, A., Putnam, L. L., \& Sivunen, A. (2020). Process studies of organizational space. Academy of Management Annals, 14(2), 797-827.

Taylor, S., \& Spicer, A. (2007). Time for space: A narrative review of research on organizational spaces. International Journal of Management Reviews, 9(4), 325-346.

Tyler, M., \& Cohen, L. (2010). Spaces that matter: Gender performativity and organizational space. Organization Studies, 31(2), 175-198.

TITLE AND KEYWORDS IN ENGLISH:

\section{Interacting in new spaces of work: A sociomaterial perspective}

KEYWORDS: workspace, interaction, organization, sociomateriality, intra-action 